neofilolog

Czasopismo Polskiego Towarzystwa Neofilologicznego

ISSN 1429-2173, 2019, NR 52/1, 159-177

http://dx.doi.org/10.14746/n.2019.52.1.12

http://poltowneo.org/

Krystyna Droździał-Szelest

Adam Mickiewicz University in Poznań

https://orcid.org/0000-0003-2376-0662

krysiad@wa.amu.edu.pl

\title{
WHAT MAKES TEACHERS DEVELOP PROFESSIONALLY: SOME REFLECTIONS ON MOTIVATIONAL ISSUES IN THE CONTEXT OF POST-GRADUATE STUDY PROGRAMMES
}

\begin{abstract}
This article explores the concept of teacher professionalism, focusing primarily on factors motivating teachers to pursue professional development within the framework of formal, organized teacher development programmes offered by educational institutions. Its major purpose is to contribute to a better understanding of motivational issues involved in teacher education, or teacher learning, as it is sometimes referred to. Its other purpose is to liven up a discussion concerning language teacher education as a life-long experience. The article consists of two parts: its theoretical sections focus on the notions of professionalism and a professional, together with the concepts of autonomy and reflection/reflective practice, which are crucial from the point of view of teacher development. Next, factors motivating teachers to continue their development both as professionals and as individuals are addressed. The second part presents and discusses results of a small-scale individual research project which yielded some interesting data pertaining to motivational issues involved in teacher learning.
\end{abstract}

Keywords: autonomy, beliefs, motivation, professional development, reflection, reflective teaching, teacher-learner ${ }^{1}$, teacher professionalism

Słowa kluczowe: autonomia, motywacja, nauczanie refleksyjne, nauczycieluczeń, profesjonalizm nauczyciela, przekonania, refleksja, rozwój zawodowy

\footnotetext{
1 'Teacher-learner' is a term introduced to refer to teachers as learners in the process of developing their professional knowledge (cf. Breen and Mann, 1997; Tort Maloney, 1997; Smith, 2000).
} 


\section{Introduction}

"The field of language teaching is subject to rapid changes, both as the profession responds to new educational paradigms and trends and as institutions face new challenges as a result of changes in curriculum, national tests and student needs" (Richards, Farrell, 2005: vii). Bearing that very fact in mind, we have to agree with Hirschhorn (2011: 48) when he claims that 'our industry', i.e. (English) Language Teaching (hence ELT), "now needs confident, eclectic teachers who, among other things, understand the value of reflection and can cope with a variety of teaching and learning contexts". As he further emphasizes,

the days are gone when we could fill new teachers up with some PPP2, add a couple of left-field techniques, wind them up and release them into the wild. We have grown into a far more demanding, technical, and 'savvy' profession and teachers today need to know much more about the research supporting just to pick a random example - the process of error correction. Teachers today can benefit from understanding the essence of (in)tolerance of ambiguity, negotiation of meaning and so on (...). (ibid.)

Thus, if they want to remain in the profession, teachers have no other choice but to keep up with its growing demands and to go on with their education. To do that, however, they have to be convinced about the need to develop, and a good starting point may be becoming aware that teacher education/development is a life-long experience which depends, primarily, on one's ability and willingness to develop and change.

There are at least two key notions that deserve closer attention when talking about teacher education, namely professionalism and a professional ${ }^{3}$ (cf. Finnocchiaro, 1988; Richards, Nunan, 1990; Ur, 1997; Bailey, Curtis, Nunan, 2001; Richards, Farrell, 2005; Zawadzka, 2004; Werbińska, 2011). Professionalism, as defined by Ur (1997: 3), means "preparing oneself to do a competent job through learning" (...) which "continues throughout the professional's working life" and

${ }^{2}$ PPP stands for Presentation, Practice and Production. In PPP classes or teaching sequences the teacher begins with presenting the context and explaining/demonstrating the meaning and form of the new language item. Then the students practice making sentences, paying attention to the form, before they are allowed to talk more freely about themselves and other people, this time focusing on the meaning (the stage of production) (cf. Harmer, 1998: 31).

${ }^{3}$ In this article, Ur's (1997) definitions of the concepts have been provided as, in the opinion of the present author, they are not only the earliest, but also, at the same time, the most comprehensive definitions of the concepts to date. 
may take different forms, including pre-service or in-service courses, reflection on experience, reading, observation, discussions with colleagues, writing, and research. A 'professional' is a term referring, broadly speaking, to "someone whose work involves performing a certain function with some degree of expertise" (ibid.). Ur asserts that "members of the professional group possess certain skills, knowledge and conventions that the lay population do not have". Furthermore, "the professional recognizes certain standards: of knowledge, of dedication and hard work, of behaviour and relationships with clients (learners, patients) and other professionals" (cf. Ur, 1997: 3).

It can be thus assumed that EFL teachers as professionals share certain characteristics; namely, they form/are a community, they are committed to reaching and maintaining certain standards of performance, they publish, communicating innovative ideas to others, they learn continually to become better educators, they are autonomous, taking responsibility for maintaining professional standards, and, finally, they are responsible for training new teachers (cf. Ur 1997: 5). As it is, to keep up with the requirements of the profession, and, more importantly, to be better prepared for their job, teachers have to go on with their educational experience, or, in other words, to pursue professional development.

\section{Teacher professional development}

The issue of teacher professional development is certainly not a new one. Back in 1986, Mary Finnocchiaro was one of the first to try to account for what was actually meant by the term. Having analysed different concepts emerging in the literature at that time, she compiled a list of areas in which "teachers should grow throughout their life time", which included:

- the awareness of their own (i.e. teachers') strengths and weaknesses;

- "more positive attitudes towards themselves, their students, their colleagues and supervisors, their communities, the needs of the country and of other countries";

- "their deeper knowledge of the social and personality factors of their students that can influence learning, of the content of their discipline (in our case, the English language), as well as of the culture and literature of English-speaking countries";

- "the enhancement of skills needed to present, practice, and appreciate the language system, literature, and culture of the target language with enthusiasm and clarity, while instilling social, moral, ethical, and cultural values in their learners" (cf. Finnocchiaro, 1988: 2).

In Finnocchiaro's opinion, the list was hardly complete without what she called 'habits' on the one hand, and the necessary knowledge and skills 
that teachers should develop on the other. ${ }^{4}$ Interestingly, she believed that there were certain qualities in teachers that could be enhanced by various teacher-development programmes (ibid.: 3-5; emphasis added).

Lange defines 'teacher development' as "a process of continual intellectual, experiential, and attitudinal growth of teachers (...) some of which is generated in preprofessional and professional inservice programs" (1990: 250). He then argues that 'development' differs from 'training', (and 'preparation') as it allows "for continued growth both before and throughout the career". Also, the very term suggests that "teachers continue to evolve in the use, adaptation, and application of their art and craft" (ibid.).

In the same vein, Richards and Farrell (2005) explain that whereas "training refers to activities focused on a teacher's present responsibilities and is typically aimed at short-term and immediate goals" (ibid.: 3), development "refers to general growth not focused on a specific job. It serves a long term goal and seeks to facilitate growth of teachers' understanding of teaching and of themselves as teachers. It often involves examining different dimensions of a teacher's practice as a basis for reflective review and can hence be seen as "bottom-up"" (ibid.: 4). It may involve, for instance, understanding how the process of second/foreign language development occurs, or reviewing teachers' own theories and principles of language learning (ibid.). They emphasize that teachers need regular opportunities for professional development which should include taking part in the following activities (2005: vii):

- engaging in self-reflection and evaluation

- developing specialized knowledge and skills about many aspects of teaching

- expanding their knowledge base about research, theory, and issues in teaching

- taking on new roles and responsibilities, such as a supervisor or mentor teacher, teacher-researcher, or materials writer

- developing collaborative relationships with other teachers.

Thus, it goes without saying that continual professional development constitutes an integral and necessary part of every teacher's life. However, we also have to remember that its ultimate goal is bringing about some kind of improvement in the way teachers teach, and/or students learn (cf. Bailey, Curtis, Nunan, 2001: 5). In other words, teacher development needs to be considered

\footnotetext{
${ }^{4}$ The knowledge and skills are important not only for the teachers' 'growth', but also their personal self-enhancement, whereas 'habits' (i.e. teacher behaviours or actions) "are conducive to a feeling of success not only in teachers but also in their learners" (Finnocchiaro, 1988: 3).

${ }^{5}$ See also Ur (1998: 21) for an in-depth discussion of the two notions, i.e. 'teacher training' and 'teacher development'.
} 
in terms of benefits such as, for instance, increased institutional effectiveness, high morale and satisfaction on the part of teachers, and effective, enjoyable learning on the part of students.

\section{Reflection and autonomy in teacher development}

Crucial from the point of view of teacher professional development are the notions of autonomy and reflection or reflective practice. There seems to be a general consensus that only teachers who are autonomous and reflective can become responsible not only for teaching, but also for their own education. Richards and Farrell (2005: 7) believe that teachers learn from experience through reflection which is viewed as "the process of critical examination of experiences, a process that can lead to a better understanding of one's teaching practices and routines". As a result, they emphasize the value of reflective teaching which consists in "collecting information on one's own teaching as the basis for critical reflection, through such processes as self-monitoring, observation, and case studies" (ibid.). Such teaching is considered to be of key importance in teacher professional development as it motivates the teacher to become autonomous, i.e. to take over the responsibility for its course and the form it takes.

Tort-Maloney (1997, in Smith 2000: 89-90) perceives the autonomous teacher as "one who is aware of why, when, where, and how pedagogical skills can be acquired in the self-conscious awareness of teaching practice itself" (emphasis added). In a similar vein, McGrath (2000: 100) views teacher autonomy in terms of taking control over one's own life, including control over one's own self-directed professional development.

Breen and Mann (1997) as well as Smith (2000) suggest that we can actually view teachers as learners (in a variety of areas) and, accordingly, that it is possible to define teacher autonomy (at least partially) in terms of the "teacher s' autonomy as a learner" - i.e. "teacher-learner autonomy" which, according to Tort-Maloney (1997, in Smith 2000: 90), is "characterized by a readiness to take charge of one's own learning in the service of one's needs and purposes. This entails a capacity and willingness to act independently and in cooperation with others, as a socially responsible person".

If we look at teacher autonomy from such a perspective, it is apparent that an autonomous teacher-learner not only has a right to choose a way of learning and the needed materials, but also a way of teaching and making decisions about the necessary resources. Likewise, $s /$ he is responsible for his/her decisions concerning goals and contents of his/her own learning, as well as goals in the process of education, his/her ability to control and evaluate, etc. Thus, what becomes of significance in the process of autonomous development 
is, according to Mc Grath (2000: 102), teachers' self-awareness as learners. ${ }^{6}$ As a result, there are many supporters of teacher education/teacher development programmes which provide experience in autonomy; i.e. programmes involving teachers in negotiation of aims, learning targets, course content, assessment of achievement, and other activities that teachers engage in on a daily basis in their teaching practice (cf. Little 1995, quoted in Mc Grath, 2000: 103). An ability to critically self-reflect is believed to mobilize the teacher-learner to think about own sources and contexts of beliefs, theories, and practices, and, accordingly, about the importance of those factors in the teacher's own relation with students.

When discussing autonomy and its role in teacher development, it seems only appropriate to emphasize the significance of choice which is a basic human right. It is kind of obvious that teachers, just like most of us, develop as professionals only if they choose to do so. Teachers may differ in their motives to develop, but, as Bailey, Curtis and Nunan (2001: 5) assert, what they have in common is "no choice, no way". "People who have no autonomy or control over what they do and are not responsible for how they do it can hardly claim to be professionals" (ibid.: 237). In other words, no one else can make a teacher develop; "if we are to develop professionally, we teachers have to do the developing for ourselves" (ibid.).

Yet another factor that deserves attention in this context are teacher beliefs. They have been given a lot of attention in the literature on teacher education because of their important role in helping teachers to make sense of what happens in language classrooms. It is especially beliefs about learners, about learning and its educational relevance, as well as teachers' beliefs about themselves (i.e. teachers' self-views) and their attitudes towards their subject and their learners (cf. Williams, Burden, 1997: 57-63) that have to be taken into consideration when discussing professional development.

As Williams and Burden (1997: 56) explain, beliefs "tend to be culturally bound, to be formed early in life and to be resistant to change", hence, they are highly influential and linked to teachers' "values, to their views of the world and to their conceptions of their place within it". More importantly, beliefs are "closely related to what we think we know but they provide an affective filter which screens, redefines, distorts, or reshapes subsequent thinking and information processing" (ibid.), which is something that many teachers

\footnotetext{
${ }^{6}$ Little (1995, quoted in McGrath 2000: 103) draws attention to yet another important aspect of autonomy in language education. In his view, learner autonomy and teacher autonomy can be treated as interdependent. As he explains, "language teachers are more likely to succeed in promoting learner autonomy if their own education has encouraged them to be autonomous".
} 
may not realize. For Williams and Burden it is crucial that "teachers should be aware of their belief systems and constantly monitoring how far their actions reflect those beliefs or are in keeping with them" (ibid.: 55). They perceive reflective teaching as having an important role to play in bringing to conscious attention what is implicit, i.e. making teachers' knowledge, views, opinions etc. clear and explicit, including teachers' beliefs about the value of and the need for continual education.

Summing up, it has to be emphasized once again that there is no professional development without autonomy and reflection, as not only do they account for teachers' ability to engage in the process, but also they motivate teachers to take over responsibility for the process and the course it takes. However, as Lange (1990: 255) states, "lifelong learning must be a construct in every teacher development program". Also, they need to be convinced that "(...) professional development is indeed worth pursuing" (Bailey, Curtis, Nunan, 2001: 4).

\section{Reasons for pursuing professional development}

Pursuing professional development is an autonomous decision of every teacher, but the reasons behind it may be many and varied. As Bailey, Curtis and Nunan (2001: 243) explain, "professional development is influenced by situational variables, because language teaching and learning occur in social contexts, and factors inherent in those contexts impinge upon teachers' work". Also, the process can be looked at both from the point of view of the individual teacher, in which case it focuses on the teacher's own personal goals, or from the point of view of an institution, where the focus is on understanding the context in which s/he works - its nature, values, etc., as well as complying with the principles/requirements of the school.

Furthermore, teachers can pursue individual development, which is personal in nature, or they can decide to take part in an organized course or a programme. Individual development usually involves focus on self-awareness and self-observation, the practice of reflective teaching, keeping a teaching journal and writing an autobiography, and compiling a teaching portfolio. Teachers may also become involved in conducting their own action research, learning another language, etc.

Nowadays, rather than pursuing individual development, many teachers choose to take part in organized courses/programmes, even though such courses may not always be geared towards their real needs. According to Hirschhorn, trainee teachers/teacher-learners often "hurl themselves headlong through hoops of quasi-academia, instead of focusing on developing attributes of a good teacher" (2011: 50). They do not realize that some courses, especially those organized by higher education institutions, may follow an over-academic 
model, ignoring the fact that "being academic or having the ability to pass exams is not part of what creates a good teacher" (ibid.). Also, another reason may be that such courses are considered as reliable and professional, being organized by experts in the field. Last but not least, their chief advantage seems to be built-in formal assessment procedures as well as the fact that upon their completion participants are provided with certificates.

Richards and Farrell (2005) claim that in spite of some disadvantages, such courses, in many cases, are beneficial from a motivational point of view. Bearing in mind that motivation is dynamic in nature and it fluctuates over time, such courses, if well planned and executed, can raise teacher-learners' motivation. For instance, they provide a forum where teacher-learners encounter colleagues or teachers from different schools with whom they can share problems and concerns as well as discuss different issues. As a result of working and/or talking with other teachers, a teacher-learner may then become more motivated to participate in other professional development projects. In addition, teacher-learners may become more self-confident both as individuals and as professionals.

Even though there have not been too many studies concerned with investigating motivational factors accounting for teachers' decisions to engage in professional development, the ones conducted to date allow us to come up with quite a comprehensive list of such factors as revealed by teachers working in different contexts. They include:

1. Increasing knowledge in the areas relevant for the teaching profession;

2. Acquiring new knowledge and skills - e.g. new techniques to use in class to solve a problem or to introduce variety and novelty;

3. Developing self-awareness - i.e. knowledge of oneself as a teacher;

4. Deepening one's understanding of learners, of curricula, and instructional materials;

5. Keeping up with change - as the world around is changing, it is necessary to become acquainted with e.g. new technologies, regulations and policy, etc.;

6. Making one more competitive on the job market - professional development may bring about an increase in income and/or prestige; it may also result in personal advancement and promotion;

7. Gaining power - "by increasing our knowledge base, we increase our power over our own lives"; "participating in appropriate professional development opportunities can lead to both empowerment and inspiration" (Bailey, Curtis, Nunan, 2001: 7);

8. Combating negativity in teachers' educational contexts (cf. Bailey, Curtis, Nunan, 2001; Richards, Farrell 2005). 
9. Preventing or combating burnout which manifests itself in emotional exhaustion, depersonalization, and lack of personal accomplishment (Maslach, 1982: 3; quoted in Bailey, Curtis, Nunan, 2001: 9);

10. Overcoming the sense of isolation on the part of the teacher-participating in professional development opportunities makes it possible for teachers to meet "like-minded people", to build a network of professionally active people;

11. Expanding teachers' conceptual understanding of teaching and their vocabulary for discussing that knowledge - being able to talk confidently with administrators, parents, students and other teachers about what we do and why we do it; "gaining confirmation and reaffirmation that what we do is worthwhile" (cf. Bailey, Curtis, Nunan, 2001: 10).

It has to be remembered, however, that, as stated at the beginning of this section, learning and teaching take place in different educational contexts, so reasons to continue professional development may vary depending on the circumstances under which a teacher or a group of teachers function. Nevertheless, knowledge about motivational factors believed to have an impact on teachers' decision to take part in teacher development programmes is of significance for many reasons.

\section{The study}

The data reported on below come from a small-scale study conducted among participants of a post-graduate study programme addressed to teachers of English as a foreign language. The original purpose of the study was to seek teachers' opinions concerning the form and the content of the programme they had completed. As it turned out, however, the study yielded a lot of interesting data pertaining to motivational issues involved in institutionalized teacher learning.

The data were obtained from 16 respondents by means of a questionnaire which, originally, was e-mailed to $\mathbf{5 0}$ graduates (former participants) of the programme. However, as the researcher was the respondents' teacher, she could also rely on additional sources of information such as observation, (field)notes, and talks with the course participants taking place during regular classes.

The questionnaire consisted of three parts; in the first one (Part A) the respondents were requested to provide their biographical data, and additionally, there was a question inquiring about other forms of professional development that they participated in, and another one, asking respondents about professional burnout. The second part of the questionnaire (Part B - 12 items) contained open-ended questions related to different aspects of their teaching - be it language teaching or the teaching of other school subjects (where applicable). 
The last part (Part C -9 items) focused on the form and content of the programme they had completed and its perceived relevance for their professional and/or personal development. The language of the questionnaire was Polish to avoid any possible misunderstandings, but the respondents had a choice - they could provide answers either in Polish or in English, if they wished to do so. As it turned out, the respondents felt more comfortable addressing the questions in Polish, hence their answers had to be translated into English for the sake of the present analysis. It is worthy of note that the majority of respondents provided very detailed, and, hence, informative answers which allow to formulate some interesting conclusions concerning their views on professional development.

When it comes to the respondents' biographical data, there were 12 females and $\mathbf{4}$ males in the sample, coming from different parts of Poland. As far as their age is concerned, there were 4 teachers in the age range of 25-29 years, $\mathbf{9}$ - in the 30-39, $\mathbf{2}$ - in the 42-46 years age range, and $\mathbf{1}$ teacher over the age of $\mathbf{5 0}$ ( 52 years of age). With reference to their teaching experience, the largest group were complete novices, with 1-2 years of experience (6), four (4) respondents had been teaching for the period of $\mathbf{4}$ to $\mathbf{6}$ years, $\mathbf{3}$ had a teaching experience between $\mathbf{8}$ and $\mathbf{1 2}$ years, and the remaining two (2) had been teaching for $\mathbf{1 6}$ and $\mathbf{1 8}$ years respectively. There was also one (1) participant who had never worked as a language teacher and was just beginning her career. In terms of their education/qualifications, $\mathbf{6}$ teachers were graduates of English Language Departments (with an M.A. diploma), 5 teachers graduated from other language departments (e.g. German, Spanish, Russian, Japanese) with English as their second major, and the remaining ones (5) were graduates of different university faculties (e.g. Pedagogy, Economics, Psychology, Political Sciences, Natural Sciences), however, they all had diplomas certifying their proficiency in English at a $\mathbf{C 1}$ level. The respondents worked in all kinds of an educational context, including state schools, higher education institutions, and private language schools.

Since the major focus of this article are motivational issues, an obvious question to start from is the one referring directly to reasons behind the participants' decision to take part in an organized form of professional development, in this case a post-graduate study programme (Question 1, Part C). As it turned out, the answers provided by the respondents were not very original. Nine (9) of them stated that their main reason for enrolling in the programme was the need to comply with formal requirements. Basically, they wanted to obtain the necessary, sometimes new, certified professional qualifications ("to get pedagogical qualifications", "to become a fully-fledged teacher", "to get the required papers/to get the required papers in order"). Other reasons included enriching knowledge in the areas of general didactics and language teaching; refreshing 
one's views on education and ways of teaching; deepening knowledge about the newest methods/trends in language teaching. As one teacher commented: I felt the need; I was afraid of "getting into a rut". Another one spoke about the need to "charge his/her batteries" and the necessity to refresh/up-date his/her knowledge, in addition to "getting the required papers in order". Yet another one also pointed to the necessity to upgrade her qualifications, but at the same time she admitted that she felt the need to satisfy her own ambitions.

On the whole, a rather short list of factors which respondents considered of significance in terms of having an impact on their decision to enroll in the programme may seem a bit disappointing, especially in comparison with some other data. However, as it turned out, the respondents' answers to subsequent questions provided more information on the topic. For instance, responses to Question 2/Part C, inquiring about professional competences they expected to develop/improve in the course of the programme, may suggest that respondents were not fully satisfied with various aspects of their professional competence and that they felt the need to change the situation. First and foremost, they pointed to cultural competence as the one they wanted to develop/improve, followed by information technology (IT) competence, and 'language teaching competence' (Pol. 'kompetencja metodyczna/ dydaktyczna'). Some of them expressed the need to develop and/or improve all competences which account for professionalism in language teaching.

Another question allowing to better understand teacher-learners' motives is the one asking them to indicate roles they found most difficult to perform in class and to provide justification for such a situation (Question 10/B). As their answers show, the roles some of them had problems with included those of a class tutor (because of lack of experience on the part of the teacher in question, as well as because of administrative chores involved); an evaluator - as the teacher explained, s/he "hated" giving marks as she was never sure whether they were fair; however, she added that she always made a decision on the final grade together with students; an innovator (as the teacher admitted, s/he liked working with a coursebook and hated creating his/her own exercises; s/he explained that when s/he was at school, teaching was not very innovative, so for him/her it was very difficult to break the routine); a researcher (recognized as a very important role which, among other things, allowed to better understand the "students' situation", as well as to become aware of their current needs and expectations). One of the respondents admitted that all teacher roles were difficult to him/her, as they were something new; at the same time, however, s/he did not find any of them overwhelming.

When evaluating different courses in terms of their usefulness from the point of view of professional development (Question 3/C), teacher-learners 
indicated the following ones: teaching young learners, ELT (methods, interaction in the classroom); language acquisition course, psycho-pedagogy, IT, and vocal emission. One respondent expressed an opinion that from his/her perspective all courses were very useful. Unfortunately, except for two brief comments, the respondents did not elaborate on the subject. One respondent explained that the course she participated in made her conscious of the mistakes she made when teaching young learners, and another one praised what she called a very practical aspect of the psycho-pedagogy course and expressed an appreciation for having an opportunity to discuss issues in class.

Question 4/C, in which teacher-learners were asked to indicate courses they considered beneficial for their personal development, turned out to be a bit problematic, as some of them found it difficult to distinguish between professional gains and personal ones. Nevertheless, they pointed to the following courses: language courses; vocal emission (I realized problems connected with using one's voice in the classroom and the necessity to control it); teaching practice (as it allows to discover your teaching skills); the so-called psycho-pedagogy course (which makes one aware of individual differences and the way they influence learning and achievement); "language didactics" i.e. ELT methodology (you can look at yourself as a teacher/makes one aware of oneself as a teacher); and, finally, an IT course (provides you with skills useful in life).

Additionally, answering Question 6/C, the respondents admitted that topics/issues discussed during classes contributed to their better understanding of what happens in a language class. Among such topics/issues, the following were found to be of particular importance: language acquisition theories, which, according to teacher-learners help one understand how students learn; teacher and learner roles in the classroom - make one aware of oneself as a teacher ("what kind of teacher I am"). Other topics/issues included: individual differences; the structure of the lesson; teaching styles, ways of conducting a lesson; new teaching techniques/proposals - e.g. projects.

Responses to questions 10/B and 3, 4 and 6 (part C) show that, on the one hand, respondents were able to recognize various problems they had with different aspects of classroom practice. On the other hand, however, they seem to suggest that respondents may have found it difficult to articulate their real motives or that they had not been aware of all their needs and lacks at the time of decision-making.

Responses to question Question 7/C, whose purpose was to find what teacher-students learnt about their own teaching and themselves as language teachers, provide further evidence that organized professional development courses may not only be motivating in themselves, but also that they can raise their participants' motivation. Thus, it seems that as a result of taking part 
in the programme, some teacher-learners gained confirmation that what they had been doing was right (It turned out I have quite good intuition about teaching and make quite a good teacher; I realized I make a good teacher/can be a good teacher; (t's not too bad!), whereas others found an explanation or justification for their practices and beliefs (I like alternative education which does not pay that much attention to rigid discipline; (...) I used projects without knowing about it; (...) I rely on partnership with my students). It was also motivating for participants to meet other teachers ('Talking to other people was invaluable') and to find out that they 'have similar problems and achievements'. Additionally, some of them claimed that 'the programme inspired them to introduce some changes into their ways of teaching'. However, as other respondents admitted, at the same time the programme made them realise that 'they were not perfect' and that 'there was a long way ahead of them if they wanted to become real professionals'.

On the whole, it seems that respondents felt the need/were motivated to develop as teachers, which is further substantiated by their answers to questions concerning different forms of such an activity. For instance, with respect to respondents' former experience with different forms of development (Question 5/A), it turned out that only $\mathbf{5}$ of them did not participate in any form of such an activity. ${ }^{7}$ Out of those who did, only 4 were encouraged and supported by the institution they worked for, whereas $\mathbf{7}$ sought different forms of development on their own initiative. These included different kinds of short-term courses offered by local teacher development centres or local educational authorities, conferences and workshops organized by publishing houses and/or professional organizations, but also teacher training/development courses abroad. Two (2) teachers reported taking part in as many as $\mathbf{1 0}$ and $\mathbf{1 1}$ of such activities, and the remaining $\mathbf{5}$ mentioned $\mathbf{3}$ to $\mathbf{5}$ opportunities they took advantage of.

Finally, answers to Question 12/B provide information about individual forms of development that teacher-learners engaged in to better understand their teaching. As the responses show, five (5) of them did not engage in any activities of that kind (cf. note 7), although one (1) person declared that she would like to use questionnaires to get some feedback on her teaching. The remaining ones mentioned different forms of activities which included: reflecting-in-action and modifying the course of the lesson on the spot if the need arises; talking to students (teenagers) during breaks and after class; taking notes and administering questionnaires on a regular basis; observing students; using student questionnaires; also, planning lessons carefully and reflecting on their course trying to find out why something went

\footnotetext{
${ }^{7}$ It has to be remembered that there were 5 novice teacher-learners in the group, including the one who was just about to begin her career as a language teacher.
} 
wrong with a given activity or, on the contrary, what made it successful (reflectionon-action); (for the time being), engaging in self-reflection on one's own classes and talking to other teachers about shared problems; collaborating with a friend teaching in the same school ${ }^{8}$; using a questionnaire at the end of the course. Three (3) respondents added that their schools (private institutions) regularly administered questionnaires and made their results available to teachers. As one of the teachers explained, she usually analyzed students' opinions and remarks and tried to take them into consideration, as she believed them to be unbiased/honest, and thus helpful. It is also worth mentioning that teacher-learners who claimed to have been involved in individual forms of development, expressed the need to devote more time to such activities, complaining at the same time about lack of time.

A few words of explanation seem to be in order at this point. On the whole, present findings seem to suggest that the respondents were not only aware of the need to develop professionally, but also that they were willing/motivated to actively pursue such development. Hence, it can be assumed that they were largely conscious of their motives, which, in most cases, is probably related to their capacity to function as reflective practitioners. As it turned out, however, there were a number of instances where the motives were difficult to interpret. In other words, teacher-learners were not always able to explicitly articulate reasons behind their decision to take part in an organized form of professional development. Additionally, some of them were not quite consistent in their answers. For instance, as many as four (4) admitted that they actually experienced, to a certain extent, problems with professional burnout (Part A, Question 1). ${ }^{9}$ It comes as a surprise then, that combating professional burnout was not mentioned as a reason for engaging in some form of development. In the same vein, it was interesting to discover that respondents did not feel the need to improve their language proficiency (in terms of linguistic or communicative competence $)^{10}$, even though they appreciated the

\footnotetext{
${ }^{8}$ The teacher further explained that as they taught the same age groups and levels of advancement, they could choose the same coursebook and plan their lessons together, helping each other.

${ }^{9}$ In one case, as the respondent explained, burnout was triggered by administrative chores (writing reports, filling in different forms, "producing" documents of different kinds). Another respondent complained about not being appreciated by her superiors and colleagues, and yet another revealed that she kept getting signals from other staff members that her ideas were too innovative for their teaching context. The respondent, who actually admitted to have experienced symptoms of burnout, explained that even though she worked both in the public and the private sectors, the problem appeared only in the context of a private language school.

${ }^{10}$ It was evident that quite a few of them had language problems, as illustrated by their oral and written performance in English during classes.
} 
so-called "practical English classes" and they perceived the 'language aspect' of the programme as a factor which contributed to their personal development.

As a further analysis of the responses shows, there were quite a number of aspects of classroom teaching which could be identified as requiring improvement and/or change, but, unfortunately, they were not explicitly recognized as such. Among problem areas mentioned there were teacher roles, teaching young learners, using a textbook, evaluation, assessment, etc. Again, a possible explanation may be that teacher-learners became conscious of those problems as a result of reflection triggered by their participation in the programme.

As mentioned elsewhere, it is worth pointing out that for some participants the programme itself was not only a source of new knowledge, skills and ideas ${ }^{11}$, but also a source of motivation in that it contributed to developing their self-awareness and/or deepening teacher-learners' understanding of their learners and the learning process (the two factors are usually high on the list of motivational factors reported by other studies). Additionally, the programme was perceived as an opportunity to exchange views and/or beliefs concerning teaching and to reflect on teaching practices. As some teacher-learners' admitted, they were going to further pursue knowledge concerning some of the topic areas covered during different courses. All in all, their responses provide support for the claim that well-organized teacher development courses can raise their participants' motivation, boost their self-esteem, develop confidence, and, in general, contribute to their positive self-image as language teachers.

Summing up, as findings of the present study clearly show, teacherlearners' motives were predominantly very pragmatic, which is hardly surprising bearing in mind their educational background. ${ }^{12}$ In that the findings are different from the ones reported by other studies, where, for instance, respondents were also motivated by personal gains (i.e. making one more competitive on the job market, gaining power, overcoming the sense of isolation; cf. pp. 168-169). It is quite optimistic though, that quite a few respondents admitted that actually they felt the need to look for new, improved ways of teaching, being aware that the ones they had at their disposal may not be adequate in a situation when they would be required to respond to a new and diversified range of learner needs in a variety of contexts. Interestingly, there

\footnotetext{
${ }^{11}$ After completing the course, some respondents expressed an opinion that they actually improved the competences they wanted/expected to improve, which is quite optimistic. ${ }^{12}$ As noted elsewhere, more than half of respondents (10) did not graduate from English language departments and, as a result, they lacked the necessary "terms of the trade" which would allow them to become "fully-fledged members of the language (English) teaching profession".
} 
were teacher-learners for whom the very possibility of "getting out of the rut" was a strong motivator.

Even though the study provides some interesting insights into motivational factors involved in decisions concerning teacher professional development, its results have to be treated with caution as they are likely to differ for another group of respondents. It is important to bear in mind that the number of respondents was rather small and that the composition of the group was rather unusual in that it included quite a few novices as well as graduates of other philology departments. Also, as the original focus of the study was different, the number of questions relating explicitly to motivational issues was rather limited and only some responses were valid from the point of view of the present analysis. As teachers work in different contexts, their attitudes towards professional development and reasons to pursue it are likely to differ as well, depending on their educational background, teaching experience, beliefs, level of autonomy and the ability to engage in reflective practice. These factors will definitely have to be taken into consideration when trying to account for motivational issues involved in teacher professional development.

\section{Conclusions, pedagogical implications and suggestions for further research}

Needless to say, bearing in mind a rather informal nature of the study and its other limitations, any conclusions based on its findings must be considered tentative. It is a fact though that, first and foremost, teachers must realize the value of professional development, they must want to learn, i.e. to be willing and motivated to devote their time and effort to the process of becoming professionals. As Bailey, Curtis and Nunan (2001: 246) assert, "professional development is not something that just happens: It must be actively pursued!"; they emphasize at the same time that motivation has a major role to play in the process.

Among factors having an impact on motivation, Williams and Burden (1997) list beliefs, including, among others, teacher-learners' beliefs about themselves (i.e. teachers' self-views), as well as beliefs about continual education and its relevance for acquiring the status of a professional. In their opinion beliefs, because of their importance, should be given due attention and attempts to change them should be undertaken when necessary. The teachers need to be convinced that what they are doing is, first of all, worth doing and that they will be able to deal with any potential problems successfully.

It is argued that these are primarily autonomous, reflective teachers who benefit from professional development, as they are the ones who are aware of why, when, where, and how they can develop and/or improve their pedagogical skills (cf. Tort-Maloney, 1997). Accordingly, reflective teaching is 
viewed as having an important role to play in bringing to teachers' conscious attention what they may be unaware of; in other words it helps teachers make sense of their knowledge, views, opinions etc., including their beliefs about the value of and the need for continual education.

As far as pedagogical implications are concerned, it is suggested that research on motivational factors could be useful in terms of designing professional teacher development programmes. Clearly, people involved in teacher education/teacher development need to be concerned with and pay close attention to motivational levels of teacher-learners so that they will be willing to invest the time and effort which is required to succeed in professional development. Even though continual development is believed to be "the responsibility of individual language teachers, rather than the schools, programs, or universities for which they work" (Bailey, Curtis, Nunan, 2001: 238; see also Lange, 1990), it is this author's contention that teacher-learners should be provided with an opportunity to participate in well-organized courses, tailored to their participants' needs, wants and lacks, which could become an additional source of motivation, serving to maintain or to revive teachers' interest in and enthusiasm for teaching (cf. Richards, Farrell, 2005).

More than two decades ago, Edwards (1996: 100) suggested that “(...) the process of learning to be an effective teacher in many ways parallels the process of learning to be an effective language user (...)". Just as language learners/users must do the learning for themselves, so must teachers learn to teach through teaching. Thus, effective teacher education courses should include, among other things, teaching practice activities to provide teacher-learners with the opportunity to learn through teaching. He strongly emphasized, however, that both groups, i.e. language learners/users and teachers "need motivation to engage in their learning activities" (ibid.; emphasis added).

Additionally, knowledge about what motivates teachers to develop could be helpful in terms of deciding on the form and content of potential courses, which should be based on a detailed analysis of and geared towards their participants' needs (tailored courses). Classes based on reflection as well as discussion relating to one's own practice should definitely constitute an important part of such programmes.

Summing up, professional development programmes should constitute an inseparable part of teacher education, as development in the changing world is simply indispensable. Equipped with the knowledge and experience coming from such instruction, teacher-learners would not only be capable to better understand both their own learning and the process of teaching, but also they could take control over it, thus becoming better and more successful language teachers. As educators of others, teachers seem to feel the need to 
participate in on-going development and change in their professional lives. However, we should be cognizant of the fact that the reasons - motives - for which teacher-learners pursue development, are many and varied.

As far as suggestions for future research are concerned, it goes without saying that more studies of different nature are needed for a better understanding of how teacher-learners develop, what factors influence the process, and what can be done to make it more effective. Such studies should definitely rely on different instruments of data collection and should take into account different educational contexts in order to ensure higher validity and reliability.

\section{REFERENCES}

Bailey K.M., Curtis A., Nunan D. (2001), Pursuing professional development. Boston, Mass.: Heinle \& Heinle.

Breen M.P., Mann S.J. (1997), Shooting arrows at the sun: perspectives on a pedagogy for autonomy (in) Benson, P., Voller, P. (eds.), Autonomy and Independence in Language Learning. London/New York: Longman, pp. 132-149.

Edwards C. (1996), Learning to learn how to teach: developing expertise through experience (in) Willis, J., Willis, D. (eds.), Challenge and change in language teaching. Oxford: Heinemann, pp. 99-107.

Finocchiaro M. (1988), Teacher development: a continuing process (in) "English Teaching Forum", No 26, pp. 2-5.

Harmer J. (1998), How to teach English. Harlow, Essex: Longman.

Hirschhorn S. (2011), Initial teacher training 1 (in) "English Teaching Professional", July, Issue 75, pp. 50-52.

Hirschhorn S. (2011), Initial teacher training 2 (in) "English Teaching Professional", September, Issue 76, pp. 48-51.

McGrath I. (2000), Teacher autonomy (in) Sinclair B., McGrath I., Lamb T. (eds.), Learner autonomy, teacher autonomy: Future directions. Harlow: Longman, pp. 100-110.

Lange D.L. (1990), A blueprint for a teacher development program (in) Richards J.C., Nunan D. (eds.), Second Language Teacher Education. Cambridge: Cambridge University Press, pp. 245-268.

Little D. (1995), Learning as dialogue: the dependence of learner autonomy on teacher autonomy (in) "System", No 23, pp. 175-182.

Richards C.J., Farrell, T.S.C. (2005), Professional development for language teachers. Strategies for teacher learning. Cambridge: Cambridge University Press.

Richards J.C., Nunan D. (eds.) (1990), Second language teacher education. Cambridge: Cambridge University Press. 
Smith R. (2000), Starting with ourselves: teacher-learner autonomy in language learning (in) Sinclair B., McGrath I. and Lamb T. (eds.), Learner autonomy, teacher autonomy: Future directions. Harlow: Longman, pp. 89-99.

Tort-Maloney D. (1997), Teacher autonomy: a Vygotskian theoretical framework. CLCS Occasional Paper no. 4. Trinity College, Dublin: Centre for Language and Communication Studies.

Ur P. (1997), The English teacher as professional (in) "English Teaching Professional", July, Issue 8, pp. 3-5.

Ur P. (1998), Distinctions and dichotomies - teacher training, teacher development (in) "English Teaching Professional", January, Issue 2. 21.

Williams M., Burden R.L. (1997), Psychology for language teachers. Cambridge: Cambridge University Press.

Willis J., Willis D. (eds.) (1996), Challenge and change in language teaching. Oxford: Heinemann.

Werbińska D. (2011), Developing into an effective teacher of English. Słupsk: Wydawnictwo Naukowe Akademii Pomorskiej w Słupsku.

Zawadzka E. (2004), Nauczyciele języków obcych w dobie przemian. Kraków: Oficyna Wydawnicza „Impuls”. 